\title{
Morphometric and meristic characteristics of poor cod, Trisopterus minutus (L. 1758), from the eastern central Adriatic Sea
}

\author{
MATE ŠANTIĆ1 \\ ANA VRDOLJAK ${ }^{2}$ \\ IVANA MIKULANDRA ${ }^{3}$ \\ ARMIN PALLAORO 4 \\ ${ }^{1}$ Department of Biology, Faculty of Natural Science \\ and Mathematics, University of Split, $\breve{Z}$ \\ Ruđera Boškovića 33, 21000 Split, Croatia. \\ e-mail: msantic@pmfst.hr \\ ${ }^{2}$ Street Seget 8, 21800 Otok, Sinj, Croatia. \\ e-mail: ana.vrdoljak20@gmail.com. \\ ${ }^{3}$ Elementary School Vodice, Street S. Mićine, \\ 22211, Vodice, Croatia. \\ e-mail: ivanam@gmail.com \\ ${ }^{4}$ Institute of Oceanography and Fisheries, \\ Šet. I. Meštrovića 63, 21000 Split, Croatia. \\ e-mail: pallaoro@izor.hr

\section{Correspondence:} \\ Mate Šantić \\ e-mail: msantic@pmfst.hr
}

Key words: Teleostei; Gadidae; biometry; Adriatic
Received October 17, 2017.

Revised June 04, 2018.

Accepted June 21, 2018.

\begin{abstract}
Background and Purpose: Poor cod, Trisopterus minutus (Linnaeus, 1758) is a gadoid fish, which inhabits the Mediterranean and eastern Atlantic. The aim of present work was to investigate the morphological properties of poor cod in the eastern central Adriatic Sea by analyzing classical morphometric and meristic characteristics, and thereby investigating: a) whether there are morphological differences between males and females; b) the existence of possible homogenous or heterogeneous stock morphology; and c) the changes in morphometric characteristics with increase in body length.
\end{abstract}

Material and methods: Samples of 410 poor cod specimens (209 females, 201 males) were collected by bottom-trawl between 2014 and 2016 from five localities in the eastern central Adriatic Sea. In order to analyze biometry of the species; fifteen morphometric and eight meristic characteristics were measured.

Results and Conclusions: Total length of all specimens ranged from 8.8 to $25.5 \mathrm{~cm}$. Morphological differences between males and females was not marked. Biometric analysis of the morphometric and meristic characteristics indicated a homogenous morphology stock of Trisopterus minutus in the Adriatic Sea. Changes in some morphometric characteristics obtained in conjunction with an increase in body length showed that smaller specimens have a longer head, eye diameter, ventral fins and second anal fins than adult specimens. The negative correlation recorded for the maximum and minimum body depth indicated that the body elongated with poor cod growth. Comparison of the meristic characteristics that were published earlier show some differences between the poor cod populations inhabiting the Adriatic, Black Sea and eastern Atlantic.

\section{INTRODUCTION}

Door cod, Trisopterus minutus (Linnaeus, 1758) is a gadoid fish, which 1 inhabits the Mediterranean and eastern Atlantic coast from Norway to the coast of Morocco (1). It is common in the Adriatic Sea on the sandy-muddy bottoms between depths of 40 and $250 \mathrm{~m}$ (2). This species is serial spawner with prolonged spawning period. It spawns in the winter-spring seasons (2). They reach first sexual maturity before the end of the first year of life (3). The poor cod is an opportunistic predator whose diet consist various bottom-living prey groups, with wide range of sizes and morphologies (4). Poor cod is one of the most abundant demersal species and in the Mediterranean Sea, annual landings by 
commercial trawl fisheries fluctuated from 1191 to 3534 tonnes (5). T. minutus is one of the most abundant demersal species, and in the Mediterranean Sea, annual landings by commercial trawl fisheries have fluctuated from 1191 to 3534 tonnes (5). The biology of this species is considered to be well documented for the Adriatic Sea $(6,7,8,9)$. However, their morphometric and meristic characteristics of this abundant species have not been systematically analyzed. Some data on individual meristic characteristics of poor cod are available $(10,11,12,13,1$, 2), however, morphometric data are scant and incomplete. Some classical morphometric relations have been reported for poor cod in the Adriatic Sea $(12,2)$.

Morphological differences based on general body type have been used to distinguish and compare among species and groups. Morphometric and meristic studies have provided useful results for identifying marine fish stocks and describing their spatial distributions. However, in description of species, knowledge of its morphometric and meristic traits is necessary especially because specimens from different areas differ from one another in morphology (2).
The aim of present work was to investigate the morphological properties of poor cod in the eastern central Adriatic Sea by analyzing classical morphometric and meristic characteristics, and thereby investigating: a) whether there are morphological differences between males and females; $b$ ) the existence of possible homogenous or heterogeneous stock morphology; and c) the changes in morphometric characteristics with increase in body length.

We expect these results will provide the first complete biometric description of T. minutus in the Adriatic Sea. The presented data are a step forward in improving the knowledge of the biology of these species.

\section{MATERIALS AND METHODS}

\section{Fish sampling}

Poor cod were collected from five localities in the eastern central Adriatic Sea (Figure 1). The investigated areas are situated on the continental shelf mostly at depths of

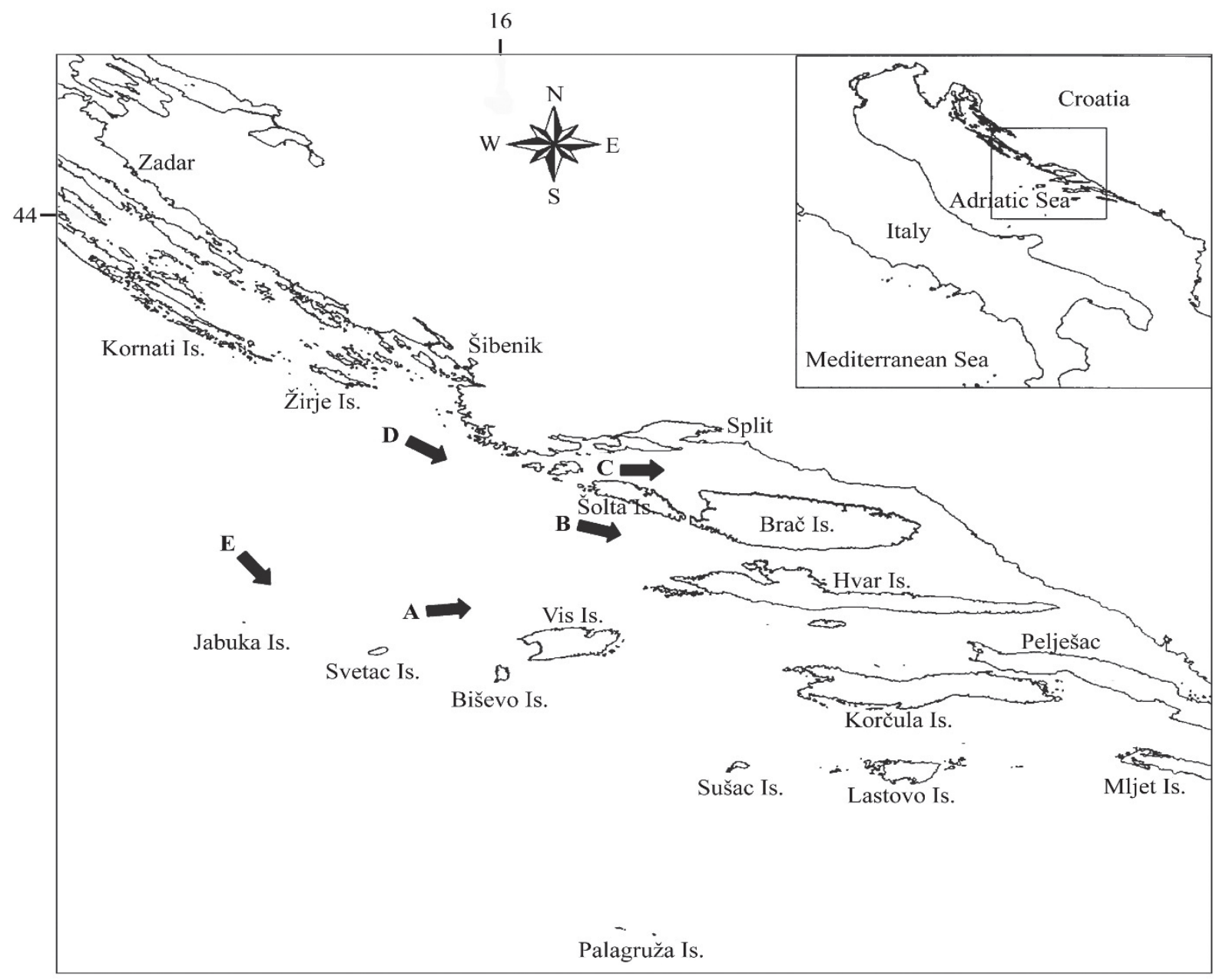

Figure 1. Study area and sampling localities of T. minutus in the eastern central Adriatic: $A-$ near islands of Vis and Svetac, B-south of Maslenica, C-Split Channel, D-Blitvenica fishing area, D-Islands of Jabuka. 


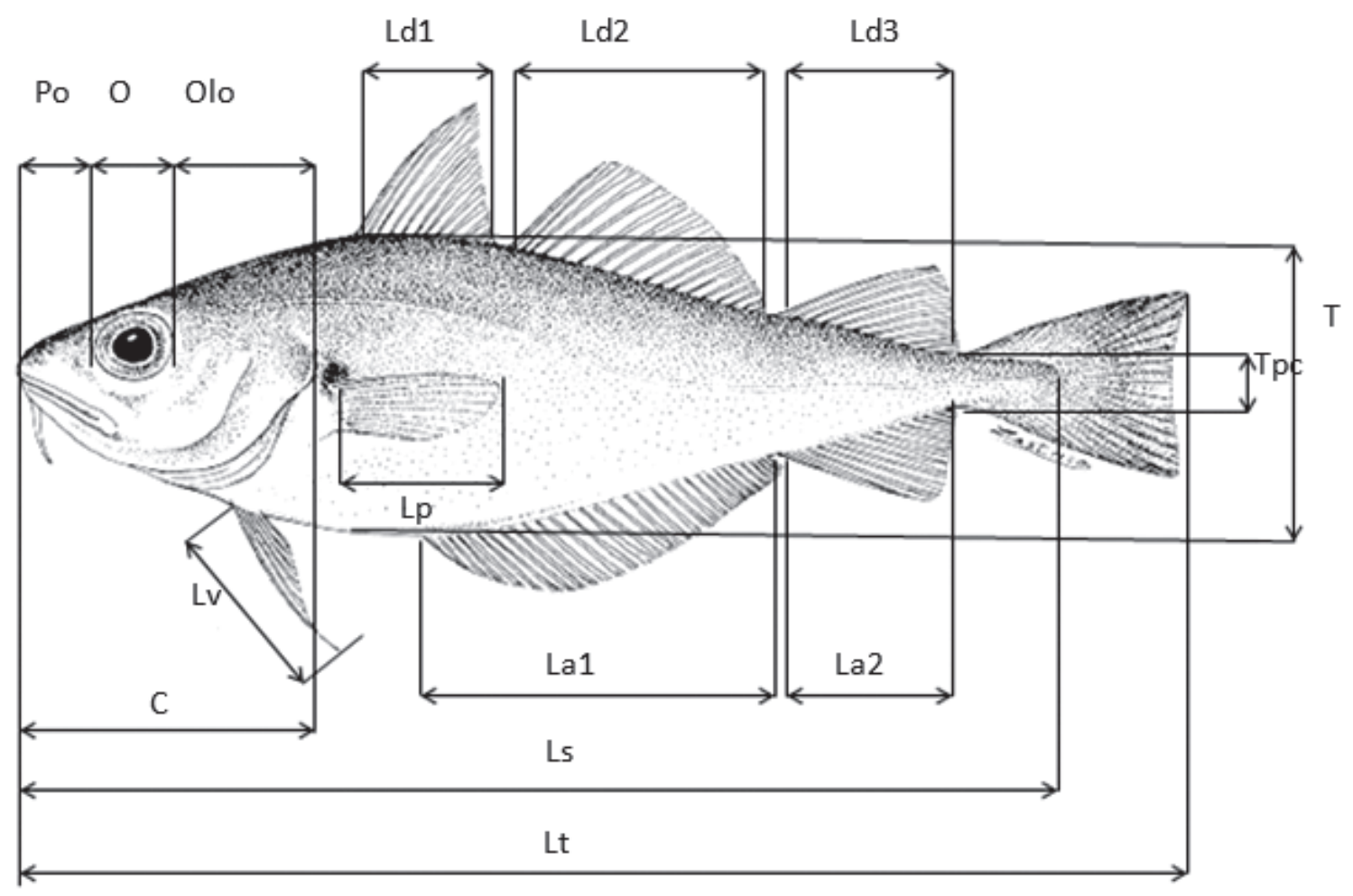

Figure 2. Morphometric measurements of T. minutus: Lt-total length, Ls-standard length, Ld1-length of first dorsal fin, Ld2 - length of second dorsal fin, Ld3 - length of third dorsal fin, La2 - length of first anal fin, La2 - length of second anal fin, Lp - length of pectoral fin $L v$-length of ventral fin, $T$-maximum body height, Tpc-minimum body height, $C$ - head length, $O$-eye diameter, Po-preocular distance, Olo-postocular distance.

90 to $120 \mathrm{~m}$. Poor cod specimens were sampled with a commercial vessel with bottom trawls using a 22-mm stretched mesh size cod-end. Duration of each haul was $2-3 \mathrm{~h}$; trawling speed fluctuated from 5 to $7 \mathrm{~km} / \mathrm{h}$. Samples were collected from 2014 to 2016, with a total of 410 specimens (201 males and 209 females).

\section{Biometric measurements}

Biometric measurements were performed on fresh fish. In the laboratory, the specimens were boiled to facilitate the separation of the muscular tissue from the vertebral column. After this step, the number of vertebrae was counted. Fifteen morphometric and nine meristic characteristics were measured.

The analyzed classical morphometric characteristics are: total length (Lt), standard length (Ls), lengths of three dorsal (Ld1, Ld2, Ld3) and two anal (La1, La2) fin bases, lengths of pectoral (Lp) and ventral fins (Lv). Also, maximum (T) and minimum (Tpc) body heights, head length $(\mathrm{C})$, eye diameter $(\mathrm{O})$, preocular $(\mathrm{Po})$ and postocular (Olo) distances were measured (Figure 2).

The analyzed meristic characteristics are: number of rays in dorsal (D1, D2, D3), anal (A1, A2), pectoral (P) and ventral fins $(\mathrm{V})$, number of gill rakers on the first gill arch (G.r.) and number of vertebrae (Vert.).
The total and standard lengths were measured with a fish meter to the nearest $0.1 \mathrm{~cm}$. The other morphometric characteristics were measured with a caliper to the nearest $0.01 \mathrm{~mm}$. The entire sample was categorized into $\mathrm{cm}$ length classes. Measurements of the head were expressed as percentages of head length whereas the other body measurements were expressed as percentages of the standard length (Ls). The standard length was expressed as percentage of the total length $(\mathrm{Ls} / \mathrm{Lt})$ and minimum height was expressed as percentage of maximum body height $(\mathrm{h} / \mathrm{H})$. Sex was determined macroscopically according to the shape and appearance of gonads.

\section{Statistical analysis}

The arithmetic mean, standard deviation and variability coefficient were used in processing biometry data. Significance of differences in studied characteristics between males and females were tested with $t$-test (14). Linear regression was applied to the examined morphometric relations in comparison with an increase in total length.

\section{RESULT}

Overall, 410 specimens of T. minutus were examined for morphometric and meristic characteristics. The sample was composed of 209 females and 201 males. Total 

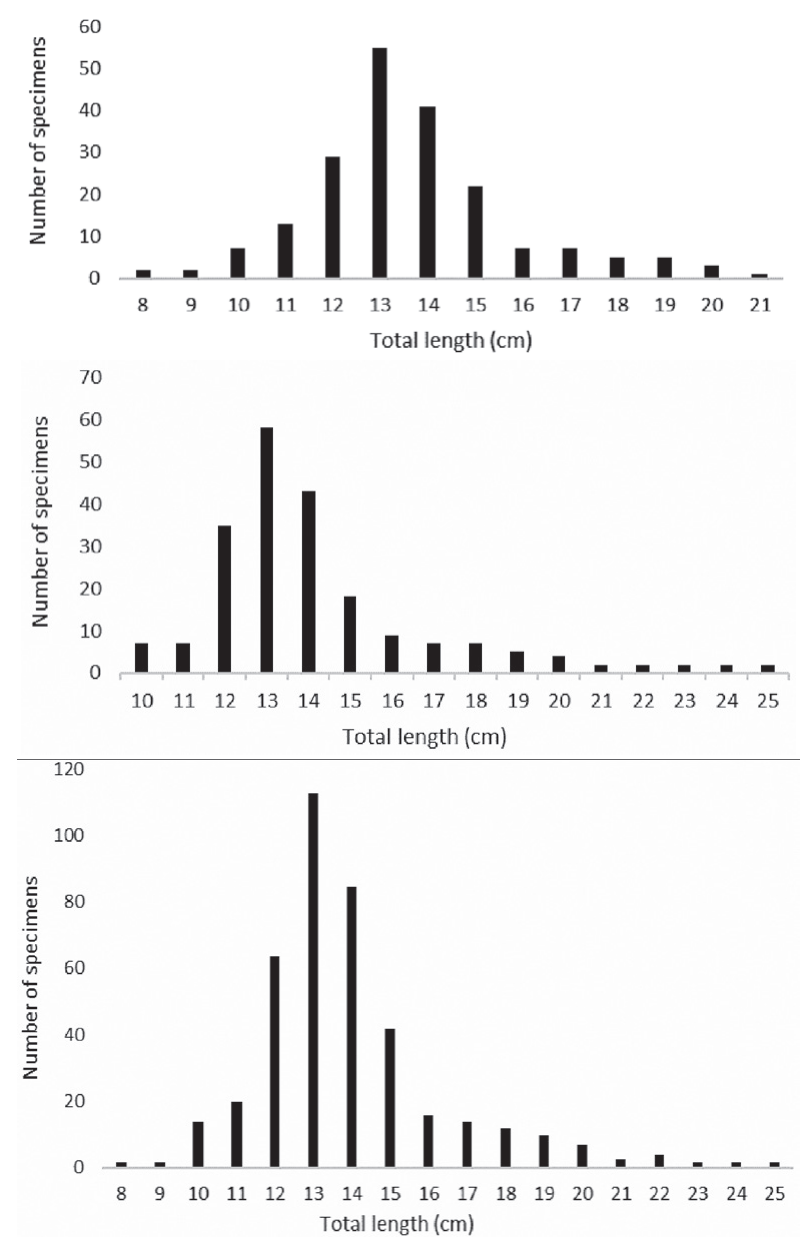

Figure 3. Length frequency distributions of $\mathrm{T}$. minutus for a) males $(n=201)$, b) females $(n=209)$ and c) total samples $(n=410)$ caught in the eastern central Adriatic

length (Lt) of all samples ranged from 8.8 to $21.5 \mathrm{~cm}$ $(14.58 \pm 1.89)$. Total length of females ranged from 10.3 to $25.5 \mathrm{~cm}(14.86 \pm 1.84)$ and males from 8.8 to $21.5 \mathrm{~cm}$ $(13.99 \pm 1.98)$. The length frequency distribution exhibited a mode at $13 \mathrm{~cm}$ (Figure 3).

Morphometric mesaurements for males, females and total poor cod sample are presented in Table 1. Morphological differences between poor cod females and males were not marked. Namely, the differences in the mean values of the measured morphometric relations between females and males were not statistically significant in any individual case. The morphometric relations for males, females and the total sample showed relatively low values of variability coefficients $(<10 \%)$ except in relation to the minimum and maximum body height (T/Tpc).

The coefficients of linear regressions for morphometric characteristics are shown in Table 2. Morphometric relations Ls/Lt, Ld1/Ls, Ld2/Ls, Ld3/Ls, La1/Ls, Lp/Ls, $\mathrm{Po} / \mathrm{C}$ and $\mathrm{Olo} / \mathrm{C}$, show positive correlation. Other measured morphometric relations (C/Ls, La2/Ls, Lv/Ls, T/ $\mathrm{Ls}, \mathrm{Tpc} / \mathrm{Ls}, \mathrm{Tpc} / \mathrm{T}, \mathrm{O} / \mathrm{C}$ ) indicate negative correlation.
TABLE 1 Relative relations of morphometric characters for females $(n=209)$, males $(n=201)$, and total sample $(n=410)$ of poor cod from eastern central Adriatic Sea.

\begin{tabular}{|c|c|c|c|c|c|}
\hline Relation & Sex & Range (\%) & Mean \pm SD & $\mathbf{t}$ & V (\%) \\
\hline \multirow{3}{*}{$\mathrm{Ls} / \mathrm{Lt}$} & $\mathrm{F}$ & $85.71-95.80$ & $90.01 \pm 2.38$ & \multirow{3}{*}{0.21} & 2.65 \\
\hline & M & $84.03-92.72$ & $89.07 \pm 1.60$ & & 1.80 \\
\hline & total & $84.03-95.80$ & $89.57 \pm 2.08$ & & 2.32 \\
\hline \multirow{3}{*}{$\mathrm{C} / \mathrm{Ls}$} & $\mathrm{F}$ & $20.49-28.83$ & $24.70 \pm 1.64$ & \multirow{3}{*}{0.16} & 6.63 \\
\hline & M & $21.43-29.17$ & $25.31 \pm 1.57$ & & 6.19 \\
\hline & total & $20.49-29.17$ & $24.99 \pm 1.62$ & & 6.49 \\
\hline \multirow{3}{*}{$\mathrm{Ld} 1 / \mathrm{Ls}$} & $\mathrm{F}$ & $10.03-14.87$ & $12.66 \pm 0.65$ & \multirow{3}{*}{0.43} & 5.13 \\
\hline & M & $10.41-15.00$ & $12.99 \pm 0.85$ & & 6.54 \\
\hline & total & $10.03-15.00$ & $12.78 \pm 0.77$ & & 6.02 \\
\hline \multirow[t]{3}{*}{$\mathrm{Ld} 2 / \mathrm{Ls}$} & F & $16.98-23.59$ & $20.49 \pm 1.49$ & \multirow[t]{3}{*}{0.76} & 7.27 \\
\hline & M & $16.51-23.40$ & $20.38 \pm 1.23$ & & 5.88 \\
\hline & total & $16.98-23.59$ & $20.42 \pm 1.32$ & & 6.46 \\
\hline \multirow[t]{4}{*}{ Ld3/Ls } & $\mathrm{F}$ & $12.90-17.55$ & $15.95 \pm 1.01$ & \multirow[t]{2}{*}{0.97} & 6.33 \\
\hline & M & $12.99-17.79$ & 15. $11 \pm 0.90$ & & 5,95 \\
\hline & total & $12.90-17.79$ & $15.64 \pm 0.98$ & & 6.26 \\
\hline & $\mathrm{F}$ & $13.97-20.19$ & $16.39 \pm 1.43$ & \multirow{3}{*}{0.14} & 8.72 \\
\hline \multirow[t]{2}{*}{$\mathrm{Lp} / \mathrm{Ls}$} & M & $14.07-20.56$ & $16.95 \pm 1.41$ & & 8.31 \\
\hline & total & $13.97-20.56$ & $16.65 \pm 1.40$ & & 8.40 \\
\hline \multirow{3}{*}{$\mathrm{La} 1 / \mathrm{Ls}$} & $\mathrm{F}$ & $20.86-29.03$ & $25.99 \pm 1.89$ & \multirow{3}{*}{0.89} & 7.27 \\
\hline & $\mathrm{M}$ & $20.98-28.90$ & $25.59 \pm 1.11$ & & 4.33 \\
\hline & total & $20.86-29.03$ & $25.80 \pm 1.54$ & & 5.96 \\
\hline \multirow[t]{3}{*}{$\mathrm{La} 2 / \mathrm{Ls}$} & $\mathrm{F}$ & $12.56-19.78$ & $15.98 \pm 0.88$ & \multirow[t]{2}{*}{0.77} & 5.55 \\
\hline & M & $12.21-19.66$ & $16.91 \pm 0.99$ & & 5.85 \\
\hline & total & $12.21-19.78$ & $16.50 \pm 0.96$ & & 5.81 \\
\hline \multirow{3}{*}{$\mathrm{Lv} / \mathrm{Ls}$} & M & $9.01-18.45$ & $14.29 \pm 1.19$ & \multirow{3}{*}{0.26} & 8.32 \\
\hline & $\mathrm{F}$ & $9.11-18.79$ & $13.88 \pm 1.22$ & & 8.78 \\
\hline & total & $9.01-18.79$ & $13.94 \pm 1.20$ & & 8.60 \\
\hline \multirow{3}{*}{$\mathrm{T} / \mathrm{Ls}$} & $\mathrm{F}$ & $20.69-32.99$ & $26.54 \pm 2.47$ & \multirow{3}{*}{0.26} & 9.31 \\
\hline & M & $23.68-34.86$ & $28.06 \pm 2.66$ & & 9.47 \\
\hline & total & $20.69-34.86$ & $27.26 \pm 2.66$ & & 9.77 \\
\hline \multirow{3}{*}{ Tpc/Ls } & $\mathrm{F}$ & $3.82-8.33$ & $6.00 \pm 0.56$ & \multirow{3}{*}{0.08} & 9.33 \\
\hline & M & $4.55-7.69$ & $6.18 \pm 0.51$ & & 8.25 \\
\hline & total & $3.82-8.33$ & $6.08 \pm 0.55$ & & 9,04 \\
\hline \multirow{3}{*}{$\mathrm{Tpc} / \mathrm{T}$} & $\mathrm{F}$ & $15.15-34.38$ & $22.59 \pm 2.48$ & & 10.97 \\
\hline & M & $16.67-27.78$ & $22.01 \pm 2.66$ & 0.34 & 12.08 \\
\hline & total & $15.15-34.38$ & $22.31 \pm 2.59$ & & 11.60 \\
\hline Relation & Sex & Range (\%) & Mean \pm SD & $\mathrm{t}$ & V (\%) \\
\hline $\mathrm{O} / \mathrm{C}$ & $\mathrm{F}$ & $28.13-38.71$ & $33.49 \pm 3.04$ & 0.33 & 9.07 \\
\hline & M & $26.67-42.31$ & $33.79 \pm 3.37$ & & 9.97 \\
\hline & total & $26.67-42.31$ & $33.63 \pm 3.35$ & & 9.96 \\
\hline & $\mathrm{F}$ & $21.05-36.00$ & $28.20 \pm 2.54$ & & 9.00 \\
\hline Po/C & M & $21.88-35.48$ & $27.96 \pm 2.50$ & 0.35 & 8.94 \\
\hline & total & $21.05-36.00$ & $28.08 \pm 2.51$ & & 8.93 \\
\hline & $\mathrm{F}$ & $51.35-67.86$ & $58.60 \pm 5.60$ & & 9.56 \\
\hline Olo/C & M & $51.43-67.88$ & $59.29 \pm 4.39$ & 0.50 & 7.40 \\
\hline & total & $51.35-67.89$ & $58.93 \pm 5.03$ & & 8.53 \\
\hline
\end{tabular}

$\mathrm{F}=$ females; $\mathrm{M}=$ males; $\mathrm{SD}=$ standard deviation; $\mathrm{t}=$ values of $\mathrm{t}$-test; $\mathrm{V}=$ variability coefficient 
TABLE 2 Regression $(a, b)$ and determination coefficients $\left(R^{2}\right)$ of linear regression for total sample $(n=410)$.

\begin{tabular}{|lcrc|}
\hline Relation & $\mathbf{a}$ & $\mathbf{b}$ & $\mathbf{R}^{2}$ \\
\hline $\mathrm{Ls} / \mathrm{Lt}$ & 92.022 & 0.078 & 0.979 \\
$\mathrm{C} / \mathrm{Ls}$ & 35.221 & -0.099 & 0.898 \\
$\mathrm{Ld} 1 / \mathrm{Ls}$ & 39.098 & 0.257 & 0.873 \\
$\mathrm{Ld} 2 / \mathrm{Ls}$ & 42.341 & 0.342 & 0.758 \\
$\mathrm{Ld} 3 / \mathrm{Ls}$ & 34.125 & 0.654 & 0.671 \\
$\mathrm{La} 1 / \mathrm{Ls}$ & 33.654 & 0.091 & 0.799 \\
$\mathrm{La} 2 / \mathrm{Ls}$ & 32.760 & -0.086 & 0.843 \\
$\mathrm{Lp} / \mathrm{Ls}$ & 20.765 & 0.104 & 0.943 \\
$\mathrm{Lv} / \mathrm{Ls}$ & 12.986 & -0.791 & 0.976 \\
$\mathrm{Tpc} / \mathrm{Ls}$ & 5.010 & -0.081 & 0.888 \\
$\mathrm{~T} / \mathrm{Ls}$ & 24.713 & -0.076 & 0.911 \\
$\mathrm{Tpc} / \mathrm{T}$ & 17.731 & -0.071 & 0.815 \\
$\mathrm{Po} / \mathrm{C}$ & 29.221 & 0.022 & 0.943 \\
$\mathrm{O} / \mathrm{C}$ & 27.121 & -0.047 & 0.923 \\
$\mathrm{Olo} / \mathrm{C}$ & 35.558 & 0.180 & 0.909 \\
\hline
\end{tabular}

Meristic data are shown in Table 3. Significant differences in meristic characteristics between males and females were not recorded (t-test). Poor cod has only soft rays in all the fins and their number varies, except in ventral fin, which compsed of six rays in all the specimens. The first dorsal fin was composed of 9-14 rays, second dorsal of 15-21 rays and the number third dorsal fin rays ranged between 14-19. The pectoral fin rays ranged between 14 and 20 . The number of gill rakers on the first gill arch ranged between 15-20, and the number of vertebrae varied from $40-45$.

\section{DIscussion}

Morphological differences between poor cod females and males in eastern central Adriatic were not observed. The relatively low values of the variability coefficient $(<$ $10 \%$ ) suggest that there was no morphological difference between the collected specimens. Values of this coefficient within populations are usually far greater than $10 \%$ in fish (15). The results in our study point to the possibility of a homogenous morphology stock of $T$. minutus in the eastern central Adriatic Sea.

The available data on the classical morphometric characteristics of poor cod are very rare. Some comparable morphometric relationships for T. minutus are presented from the Adriatic Sea $(12,2)$. Head length constitutes $27.1 \%$ of the standard length while eye diameter makes $31.3 \%$ of the head length (12). Maximum body height constitutes 25.0 $-29.4 \%$ of the standard length (2). Generally, these data are very close to the data presented in our study.
TABLE 3. Meristic characters for females $(n=209)$, males $(n=201)$ and total sample $(n=410)$ of poor cod from the eastern central Adriatic Sea.

\begin{tabular}{|c|c|c|c|c|c|}
\hline $\begin{array}{l}\text { Meristic } \\
\text { character }\end{array}$ & Sex & Range & Mean \pm SD & $\mathbf{t}$ & V (\%) \\
\hline \multirow[t]{3}{*}{ D1 } & $\mathrm{F}$ & $9-14$ & $11.23 \pm 1.06$ & 0.10 & 0.09 \\
\hline & M & $10-13$ & $11.24 \pm 0.94$ & & 0.08 \\
\hline & Total & $9-14$ & $11.24 \pm 1.00$ & & 0.09 \\
\hline \multirow[t]{3}{*}{ D2 } & $\mathrm{F}$ & $15-21$ & $18.02 \pm 1.45$ & 0.15 & 0.08 \\
\hline & M & $15-21$ & $18.38 \pm 1.52$ & & 0.08 \\
\hline & total & $15-21$ & $18.20 \pm 1.40$ & & 0.08 \\
\hline \multirow[t]{3}{*}{ D3 } & $\mathrm{F}$ & $14-19$ & $15.85 \pm 1.14$ & 0.11 & 0.07 \\
\hline & M & $13-18$ & $15.68 \pm 0.98$ & & 0.06 \\
\hline & total & $13-19$ & $15.76 \pm 1.06$ & & 0.07 \\
\hline \multirow[t]{3}{*}{ A1 } & $\mathrm{F}$ & $22-29$ & $25.69 \pm 1.44$ & 0.12 & 0.06 \\
\hline & M & $24-28$ & $25.16 \pm 0.77$ & & 0.03 \\
\hline & total & $22-29$ & $25.43 \pm 1.18$ & & 0.05 \\
\hline \multirow[t]{3}{*}{ A2 } & $\mathrm{F}$ & $12-22$ & $16.83 \pm 2.37$ & 0.21 & 0.14 \\
\hline & M & $14-20$ & $16.34 \pm 1.78$ & & 0.11 \\
\hline & total & $12-22$ & $16.59 \pm 2.10$ & & 0.13 \\
\hline \multirow[t]{3}{*}{ V } & $\mathrm{F}$ & 6 & $6.00 \pm 0$ & 0 & 0 \\
\hline & $\mathrm{M}$ & 6 & $6.00 \pm 0$ & & 0 \\
\hline & total & 6 & $6.00 \pm 0$ & & 0 \\
\hline \multirow[t]{3}{*}{$\mathrm{P}$} & $\mathrm{F}$ & $14-18$ & $15.81 \pm 1.16$ & 0.13 & 0.07 \\
\hline & M & $15-20$ & $16.40 \pm 1.39$ & & 0.08 \\
\hline & total & $14-20$ & $16.10 \pm 1.30$ & & 0.08 \\
\hline \multirow[t]{3}{*}{ G.r. } & $\mathrm{F}$ & $15-20$ & $16.94 \pm 1.16$ & 0.12 & 0.07 \\
\hline & M & $16-20$ & $17.92 \pm 1.01$ & & 0.06 \\
\hline & total & $15-20$ & $17.42 \pm 1.19$ & & 0.07 \\
\hline \multirow[t]{3}{*}{ Vert. } & $\mathrm{F}$ & $40-45$ & $41.56 \pm 1.39$ & 0.13 & 0.03 \\
\hline & M & $40-44$ & $41.94 \pm 1.19$ & & 0.03 \\
\hline & total & $40-45$ & $41.75 \pm 1.30$ & & 0.03 \\
\hline
\end{tabular}

D1 $=$ number of rays in first dorsal fin, D2 = number of rays in second dorsal fin, D3 = number of rays in third dorsal fin, A1 = number of rays in first anal fin, $\mathrm{A} 2$ = number of rays in second anal fin, $\mathrm{P}=$ number of rays in pectoral fin, $V=$ number of rays in ventral fin, G. r. = number of gill rakes on the first gill arch, Vert. $=$ number of vertebrae $(M=$ males; $\mathrm{F}=$ females; $\mathrm{SD}=$ standard deviation; $\mathrm{t}=$ values of $\mathrm{t}$-test; $\mathrm{V}=$ variability coefficient)

The coefficients of linear regressions for morphometric characteristics are shown in Table 2. These coefficients indicate that fish with a smaller body have a longer head $(\mathrm{C} / \mathrm{Ls})$, eye diameter $(\mathrm{O} / \mathrm{C})$, ventral fins $(\mathrm{Lv} / \mathrm{Ls})$, second anal fins (La2/Ls) as well as greater minimum (T/Ls) and maximum body height $(\mathrm{Tpc} / \mathrm{Ls})$. At the same time, they have shorter standard length (Ls/lt), dorsal fins (Ld1/Ls, $\mathrm{Ld} 2 / \mathrm{Ls}, \mathrm{Ld} 3 / \mathrm{Ls})$, pectoral (Lp/Ls) and first anal fins 
TABLE 4. Meristic characters of poor cod from the Adriatic Sea, Mediterranean, Black Sea and NE Atlantic.

\begin{tabular}{|c|c|c|c|c|c|c|c|c|c|}
\hline Area and data of authors & D1 & D2 & D3 & A1 & A2 & $\mathbf{P}$ & V & Vert. & G. $r$. \\
\hline $\begin{array}{l}\text { Eastern central Adriatic } \\
\text { Our results }\end{array}$ & $9-14$ & $15-21$ & $13-19$ & $22-29$ & $12-22$ & $14-20$ & 6 & $40-45$ & $15-20$ \\
\hline $\begin{array}{l}\text { Algerian waters } \\
\text { Dieuzeide et al. (1955) }\end{array}$ & $11-13$ & $16-21$ & $17-20$ & $26-30$ & $16-20$ & 19 & 6 & 39 & - \\
\hline $\begin{array}{l}\text { Italian waters } \\
\text { Bini (1970) }\end{array}$ & $11-13$ & $18-22$ & $17-19$ & $27-30$ & $18-20$ & 19 & 6 & 39 & $17-20$ \\
\hline Tortonese (1970) & $11-13$ & $16-22$ & $17-20$ & $26-30$ & $16-20$ & - & - & $45-48$ & - \\
\hline $\begin{array}{l}\text { North eastern Atlantic } \\
\text { and Mediterranean } \\
\text { Svetovidov (1986) }\end{array}$ & $12-13$ & $23-27$ & $20-25$ & $27-30$ & $20-25$ & - & - & $47-51$ & $25-32$ \\
\hline $\begin{array}{l}\text { Black Sea } \\
\text { Svetovidov (1964) }\end{array}$ & $10-12$ & $17-20$ & $15-17$ & $25-29$ & $15-20$ & - & - & - & $17-20$ \\
\hline $\begin{array}{l}\text { Adriatic Sea } \\
\text { Jardas (1996) }\end{array}$ & $8-12$ & $10-14$ & $11-16$ & $15-18$ & $12-16$ & $14-19$ & 6 & $40-45$ & $15-20$ \\
\hline
\end{tabular}

(Ld1/Ls). The negative correlation recorded for the maximum and minimum body depths points to the fact that body is progressively elongated. As to other morphometric relations, small specimens have smaller preocular $(\mathrm{Po} / \mathrm{C})$ and postocular distances $(\mathrm{Olo} / \mathrm{C})$ and a larger eye diameter $(\mathrm{O} / \mathrm{C})$ than the larger $T$. minutus specimens. Preocular and postocular distances increase relatively to the poor cod body length.

The meristic characters of poor cod from the eastern central Adriatic Sea were compared with the available literature data (Table 4). Cited literature is based only on books that describe fauna of certain areas. Therefore, there are no sample sizes or exact research areas defined.

The number of rays in the pectoral fin is defined by three authors $(10,11,2)$ and it varies from 14 to 20 . The number of rays in the ventral fin (six rays) is the almost the same in Adriatic Sea, Italian and Algerian waters. The number of gill rakers is mostly found to be from 15-20. In other hand, in the Atlantic population this number is from 25-32 (1), contrasting with the present study where this range was lower. In poor cod there are between 45-48 vertebrae. However, in Atlantic population this number can be bigger (47-51) (1). Also, Atlantic population of poor cod, show increased number of rays in second and third dorsal and second anal fins compared to those from other areas (Adriatic, Black Sea, Italian and Algerian waters). The significance of differences among reported data could not be established since only ranges of meristic data are given in literature. The meristic data from this study suggest that population of poor cod from the Adriatic Sea is slightly different in morphology compared to the Black Sea population. This differences in some meristic characteristics of poor cod from various geographical areas could be result of spatial segregation and different environmental conditions. It had been assumed earlier that variation in meristic and morphometric characteristics are entirely genetic (16), but recently it has been found that they have environmental and genetic components as well (17). The number of rays in the dorsal and anal fins from this study show greater range compared with results of Bini (11) and Jardas (2). These differences were probably related to the larger analyzed sample and wider size-interval of poor cod specimens in our study.

In conclusion, results in this study show that there are no morphological differences between males and females. Biometric analysis has revealed changes in some morphometric characteristics during fish growth and points to the possibility of the existence of a homogenous morphology stock of the poor cod in the eastern central Adriatic. Differences in some meristic characteristics between the poor cod populations in the Atlantic, Adriatic and Black Sea exist and could be the result of different environmental conditions. So, further studies should investigate the possible connection between observed variability and environmental factors.

Acknowledgments: The authors gratefully acknowledge the help of professional fisherman in collecting material for this study. We also want to thank the Croatian Ministry of Science, Education and Sports for financial support.

\section{REFERENCES}

1. SVETOVIDOV A N 1986 Gadidae. In: Whitehead PJP, Bauchot ML, Hureau JC, Nielsen J, Tortonese E (eds), Fishes of the Northeastern Atlantic and Mediterranean. UNESCO, Paris, p 680-710

2. JARDAS I 1996 Adriatic ichtyofauna. Školska knjiga d.d., Zagreb (in Croatian), p 523

3. TANGERINI P, ARNERI E 1984 Biological data collected during the Pipeta expeditions on the poor cod, Trispoterus minutus capelanus (Risso), in the Adriatic Sea. FAO Fish Rep 290: 155-159

4. ŠANTIĆ M, MIKULANDRA I, PALLAORO A, JARDAS I, STAGLIČIĆ N 2009 Diet of poor cod, Trisopterus minutus (Osteichthyes: Gadidae) from the eastern central Adriatic Sea. Cah Biol Mar 50: 183-192 
5. FAO Fish Stat 2014 Capture production

6. FROGLIA C,. ZOPINI A M 1981 Observations on growth of Trispoterus minutus capelanus (Risso) (Pisces, Gadiade) in the central Adriatic Sea. Rapp Comm Int Mer Mèdit 27: 57-60

7. GIANETTI G, GRAMITTO M E 1988 Growth of poor cod Trispoterus minutus capelanus (Lacepede) (Pisces, Gadidae) in the central Adriatic Sea. Rapp Comm Int Mer Mèdit 31: 266.

8. ŠANTIĆ M, PALLAORO A, STAGLIČIĆ N, MIKULANDRA I, JARDAS I 2010 Co-variation of gonadosomatic index, condition factor and length-weight relationships of poor cod, Trisopterus minutus (Gadidae), in the Eastern Adriatic Sea. Cybium 34 (3): 279-284

9. ŠANTIĆ M, PALLAORO A, MIKULANDRA I, RAĐA B, JARDAS I 2015 Age, growth and mortality of poor cod (Trisopterus minutus L.) from the eastern Adriatic Sea. Arch Biol Sci 67 (3): 921-927. https://doi.org/10.2298/ABS141106053S

10. DIEUZEIDE R, NOVELLA M, ROLAND J 1955 Catalogue des poissons des Côtes Algériennes. Bull. Trav Publ Stat Aquicult Pèche Castiglione 5: 1-384
11. BINI G. 1970 Atlante dei pesci delle coste Italiane, V. Osteitti. 9394. Mondo Somerso, Milano, p 229

12. TORTONESE E 1970 Osteichthyes (Pesci Ossei). Fauna d'Italia. X. Calderini, Bologna, p 565

13. SVETOVIDOV A N 1964 Fishes of the Black Sea. Nauka, Moscow (in Russian), p 550

14. SOKAL R R, ROHLF F J 1981 Biometry. W. H. Freeman and Company, San Francisco.

15. CARVALHO I 1993 Evolutionary aspects of fish distribution: genetic variability and adaptation. J Fish Biol 43: 57-73. https://doi.org/10.1111/j.1095-8649.1993.tb01179.x

16. MCQUINN I H 1997 Metapopulations and Atlantic herring. Rev Fish Biol Fisheries 7: 297-329. https://doi.org/10.1023/A:1018491828875

17. CABRAL H N, MARQUES J F, REGO A L, CATARINO A I, FIGUEIREDO J, GARCIA J 2003 Genetic and morphological variation of Synaptura lusitanica Capello, 1868, along the Portuguese coast. J Sea Res 50: 167-175 